\title{
Agreement test of transcutaneous bilirubin and bilistick with serum bilirubin in preterm infants receiving phototherapy
}

\author{
Rinawati Rohsiswatmo ${ }^{1,2}$, Hanifah Oswari ${ }^{1}$, Radhian Amandito ${ }^{2}$, Hikari Ambara Sjakti ${ }^{1}$, Endang Windiastuti ${ }^{1}$, \\ Rosalina Dewi Roeslani ${ }^{1}$ and Indrayady Barchia ${ }^{1^{*}}$
}

\begin{abstract}
Background: This study compares the minimally invasive Bilistick and a noninvasive method with standard Total Serum Bilirubin (TSB) measurement in preterm newborns receiving phototherapy. We assess the agreement of Transcutaneous Bilirubinometer (TCB) and Bilistick bilirubin measurements with standard TSB measurement in preterm infants receiving phototherapy.

Methods: Bilirubin was measured by using TCB and Bilistick in 94 preterm infants in RSCM Jakarta Neonatal Ward from October 2016 to March 2017, with gestational ages of < 35 weeks, before phototherapy and after 24 and $48 \mathrm{~h}$ of phototherapy.

Results: There was significant correlation before, at 24 and $48 \mathrm{~h}$ of phototherapy between TSB and either TCB $(r=0.874$; $r=0.889 ; r=0.878$ respectively; $p<0.0001)$, or Bilistick $(r=0.868 ; r=0.877 ; r=0.918$ respectively; $p<0.0001)$. The mean difference and limits of agreement before, at 24 and $48 \mathrm{~h}$ of phototherapy between TCB and TSB were 0.81 $\pm 1.51 \mathrm{mg} / \mathrm{dL}$ ( -2.14 to $3.77 \mathrm{mg} / \mathrm{dL}) ; 0.43 \pm 1.57 \mathrm{mg} / \mathrm{dL}(-2.66$ to $3.51 \mathrm{mg} / \mathrm{dL}) ; 0.41 \pm 1.58 \mathrm{mg} / \mathrm{dL}(-2.69$ to $3.50 \mathrm{mg} / \mathrm{dL})$, respectively. For Bilistick they were $-1.50 \pm 1.47 \mathrm{mg} / \mathrm{dL}(-4.38$ to $1.38 \mathrm{mg} / \mathrm{dL}) ;-1.43 \pm 1.47 \mathrm{mg} / \mathrm{dL}(-4.32$ to $1.46 \mathrm{mg} / \mathrm{dL}) ;-1,15 \pm 1.31 \mathrm{mg} / \mathrm{dL}(-3,72$ to $1,42 \mathrm{mg} / \mathrm{dL})$, respectively.

Conclusions: Both methods are reliable for measuring TSB before, during, and after phototherapy in preterm infants. TcB tends to overestimate while Bilistick underestimates TSB.
\end{abstract}

Keywords: Indonesia, Bilistick, Transcutaneous bilirubin, Phototherapy, Preterm infants

\section{Background}

Hyperbilirubinemia is one of the most common problems arising in the neonatal period. Hyperbilirubinemia in neonates often develops in the first week of life, ranging in frequency from $60 \%$ in term and $80 \%$ in preterm infants [1-3]. Phototherapy is still the primary treatment to prevent further complications for newborns with hyperbilirubinemia, especially for premature infants who have a higher risk of bilirubin encephalopathy [4]. During the course of phototherapy, it is necessary to monitor the bilirubin levels periodically until phototherapy is completed in

\footnotetext{
* Correspondence: indrayady@yahoo.com

${ }^{1}$ Department of Child Health, Faculty of Medicine, Universitas Indonesia Cipto Mangunkusumo Hospital, Jl Pangeran Diponegoro No. 71, Salemba, Kenari, Senen, Jakarta Pusat, DKI Jakarta 10430, Indonesia

Full list of author information is available at the end of the article
}

order to prevent overtreatment. However, regular blood taking can cause problems such as anemia and increased risk of infection in newborns with hyperbilirubinemia. The risk increases especially in preterm infants with lower blood volume and altered immune status. Serum bilirubin measurement is a gold standard for measuring total serum bilirubin (TSB) levels for both detection and evaluation during phototherapy. However, this measurement is an invasive procedure that poses a higher risk of infection, pain, and requires a rather large amount of blood [5-7]. Currently, there are several alternatives for measurement of bilirubin levels. In this study, we will be focusing on the Bilistick System. Compared to TSB, which requires large volumes of blood, the Bilistick System requires only $25 \mu \mathrm{L}$ of capillary blood. With regards to its cost, the Bilistick System is considerably cheaper than the non-invasive transcutaneous

(c) The Author(s). 2018 Open Access This article is distributed under the terms of the Creative Commons Attribution 4.0 International License (http://creativecommons.org/licenses/by/4.0/), which permits unrestricted use, distribution, and reproduction in any medium, provided you give appropriate credit to the original author(s) and the source, provide a link to the Creative Commons license, and indicate if changes were made. The Creative Commons Public Domain Dedication waiver (http://creativecommons.org/publicdomain/zero/1.0/) applies to the data made available in this article, unless otherwise stated. 
bilirubinometer (TcB); $€ 1300$ for transcutaneous bilirubin (JM 103) compared to $€ 600$ for Bilistick device (2016 Version) and $€ 1.5$ for each test strip and transfer pipette.

Several studies on transcutaneous and Bilistick bilirubin measurements have been conducted to assess the validity of both devices. The correlation between TcB and TSB results in previous studies was strong $(r=0.835 ; p<0.0001)$, but this study did not measure bilirubin levels during phototherapy [8]. A previous meta-analysis study comparing the measurement of TcB and TSB levels during phototherapy obtained $r=0.64$ (95\% CI 0.43-0.77) on the measurement of transcutaneous bilirubin in the sternal region, but this study was performed on near-term and term infants [9].

Studies comparing Bilistick and serum bilirubin showed a strong correlation $(r=0.961$ and $r=0.914 ; P<0.0001)$ but they did not include infants receiving phototherapy [10]. A study comparing bilirubin measurement using transcutaneous bilirubin and Bilistick has been recently reported, with a similar limit of agreement of the Bilistick System ( -5.8 to $3.3 \mathrm{mg} / \mathrm{dL})$ and JM-103 system ( -5.4 to $6.0 \mathrm{mg} / \mathrm{dL}$ ) versus the clinical laboratory; however, this study only involved term infants and not those being treated by phototherapy [11].

To our knowledge, no previous study has been conducted comparing the measurement of TcB and Bilistick with total serum bilirubin during phototherapy in preterm infants. The aim of this study was to assess the agreement of $\mathrm{TcB}$ and Bilistick bilirubin measurements in hyperbilirubinemic preterm infants before and during phototherapy in the hope of determining the best alternative method for measurement of bilirubin levels to reduce the risk of anemia and infections in preterm infants. This is especially important for places with limited laboratory facilities that require measurement systems that are accurate, easy to use, inexpensive, and provide fast results.

\section{Methods}

\section{Study population}

This study was conducted in the Neonatology Division of the Department of Child Health Faculty of Medicine, Universitas Indonesia - Cipto Mangunkusumo Hospital (RSCM) Jakarta. The inclusion criteria were: hyperbilirubinemic preterm infants age $\leq 14$ weeks, gestational age $<$ 35 weeks old who are receiving phototherapy in the Neonatology Division of RSCM Jakarta and with signed parental consent for inclusion in the study. Exclusion criteria were: preterm infants with a prior history of phototherapy or previous exchange transfusion and all preterm infants with defects at the site of measurement. Decision to initiate phototherapy was based on the Indonesian Pediatric Society (IDAI) guidelines for preterm infants with hyperbilirubinemia [12]. Bilirubin measurement was conducted only for the first $48 \mathrm{~h}$ of phototherapy after which the neonate received standard therapy including continued phototherapy if indicated.

\section{Laboratory investigations}

For each participating hyperbilirubinemic newborn, a thorough explanation of the research was given to the parents and parental consent to participate in the study was obtained. Identification of the patient included: name, age, gender, parent's name and relationship with parents, gestational age, and history of phototherapy. Ballard score was calculated, then the weight was measured using baby scales (20 kg with $0.1 \mathrm{~kg}$ precision) (Seca, Germany), and body length and head circumference were measured using an infantometer and measuring tape $(100 \mathrm{~cm}$ length with $0.1 \mathrm{~cm}$ precision) (Seca, Germany). For each infant, bilirubin was measured using TcB, Bilistick and total serum bilirubin lab measurement. The TcB measurement was performed 3 times in a row with Dragger JM 103 in the midsternum area, and the average of the 3 measurements was obtained. All measurements were made by a trained nurse or physician. For the Bilistick measurement, $25 \mathrm{uL}$ of capillary blood was collected by a nurse, and then applied to a test strip and inserted in the Bilistick reader. The TSB concentration is determined by reflectance spectroscopy within $3 \mathrm{~min}$ of loading.

The TSB measurement was performed by taking $0.6 \mathrm{ml}$ of venous blood, putting it into a vacuum tube, and sending it to Cipto Mangunkusumo Hospital Clinical pathology laboratory in Jakarta, where they employed the chemical oxidation method utilizing vanadate as the oxidizing agent using the ADVIA Chemistry Total Bilirubin 2 device (Siemens, Germany).

\section{Statistical analysis}

Categorical data are presented in the form of frequency distribution, proportion, and percentage, while continuousscale data are presented as mean and standard deviation or median and range. The correlation between the gold standard measurement and the tool under test was calculated using Pearson correlation (normal distribution) and Spearman correlation (abnormal distribution). Bland-Altman test was used to calculate the agreement of the mean difference between the gold standard measurement and the tested tool. The mean difference is expressed as mean $\pm \mathrm{SD}$, while the limit of agreement is calculated based on the mean \pm 1.96

\section{Table 1 Characteristics of subjects $(n=94)$}

\begin{tabular}{ll}
\hline Characteristics & \\
\hline Gender & $53(56.4 \%)$ \\
$\quad$ Male & $41(43.6 \%)$ \\
$\quad$ Female & $2.94 \pm 1.66$ (1 to 10) \\
Age (days) Mean \pm SD (range) & $31.27 \pm 2.32$ (26 to 34) \\
Gestational age (weeks) Mean \pm SD & \\
(range) & $1466.73 \pm 442.24$ (700 to \\
Weight (g) Mean \pm SD (range) & $2450)$ \\
\hline
\end{tabular}


Table 2 Profile of bilirubin levels

\begin{tabular}{|c|c|}
\hline Measurement & Bilirubin level \\
\hline \multicolumn{2}{|l|}{ Before phototherapy } \\
\hline $\begin{array}{l}\text { Total serum bilirubin (mg/dL) Mean } \pm \text { SD } \\
\text { (range) }\end{array}$ & $\begin{array}{l}10.18 \pm 2.91(4.43 \text { to } \\
19.70)\end{array}$ \\
\hline Transcutaneous (mg/dL) Mean \pm SD (range) & $\begin{array}{l}10.99 \pm 3.07(4.70 \text { to } \\
19.60)\end{array}$ \\
\hline Bilistick (mg/dL) Mean \pm SD (range) & $\begin{array}{l}8.68 \pm 2.78(4.20 \text { to } \\
14.80)\end{array}$ \\
\hline \multicolumn{2}{|l|}{$24 \mathrm{~h}$ of phototherapy } \\
\hline $\begin{array}{l}\text { Total serum bilirubin }(\mathrm{mg} / \mathrm{dL} \text { ) Mean } \pm \mathrm{SD} \\
\text { (range) }\end{array}$ & $\begin{array}{l}9.75 \pm 3.04(3.25 \text { to } \\
18.20)\end{array}$ \\
\hline Transcutaneous (mg/dL) Mean \pm SD (range) & $\begin{array}{l}10.18 \pm 3.44(1.90 \text { to } \\
19.70)\end{array}$ \\
\hline Bilistick (mg/dL) Mean \pm SD (range) & $\begin{array}{l}8.33 \pm 2.86(3.20 \text { to } \\
17.90)\end{array}$ \\
\hline \multicolumn{2}{|l|}{$48 \mathrm{~h}$ of phototherapy } \\
\hline $\begin{array}{l}\text { Total serum bilirubin ( } \mathrm{mg} / \mathrm{dL} \text { ) Median } \pm \text { SD } \\
\text { (range) }\end{array}$ & 8 (0.58 to 21.26$)$ \\
\hline $\begin{array}{l}\text { Transcutaneous (mg/dL) Median } \pm \text { SD } \\
\text { (range) }\end{array}$ & 7.9 (1.70 to 22.30$)$ \\
\hline Bilistick (mg/dL) Median \pm SD (range) & 6.85 (1.20 to 17.20$)$ \\
\hline
\end{tabular}

SD. Statistical Package for the Social Sciences (SPSS) version 18.0 for Windows was used for all statistical analyses. This research was approved by the Medical Research Ethics Committee of the Faculty of Medicine, University of Indonesia and the licensing of research sites from Cipto Mangunkusumo Hospital.

\section{Results}

During the study period, there were 120 preterm infants less than 35 weeks of gestation who suffered hyperbilirubinemia and 96 of them (80\%) had indications for phototherapy. Of these 96 infants, 2 infants were not treated with phototherapy due to clinical deterioration and eventual death. The remaining 94 infants were enrolled in the study.

The characteristics of 94 participants included in the study are reported in Table 1. There were $53(56.4 \%)$ males and 41 (43.6\%) females. The mean age of the subjects at the time of hyperbilirubinemia diagnosis was 2.9 days with a range of 1 to 10 days. The mean of gestational age of subjects was 31.3 weeks with a range of 26 to 34 weeks while mean weight of subjects was $1466.73 \mathrm{~g}$ with a range of 700 to $2450 \mathrm{~g}$.

Profiles of total serum bilirubin, transcutaneous bilirubin, and Bilistick levels before phototherapy, and after $24 \mathrm{~h}$ and $48 \mathrm{~h}$ of phototherapy are reported in Table 2.
A

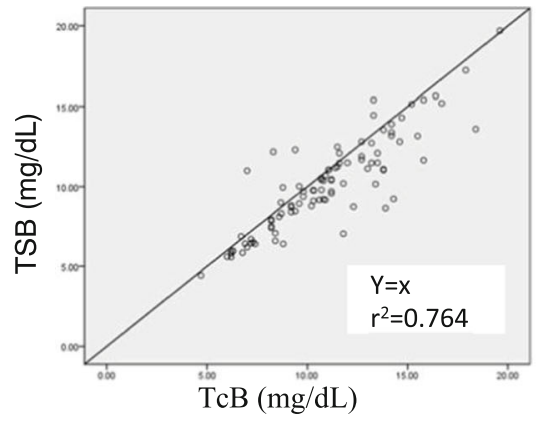

C

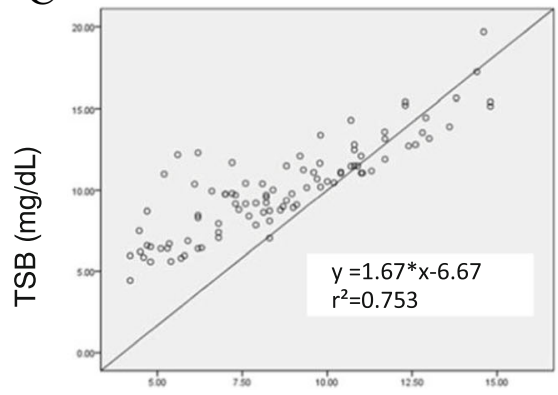

Bilistick (mg/dL)

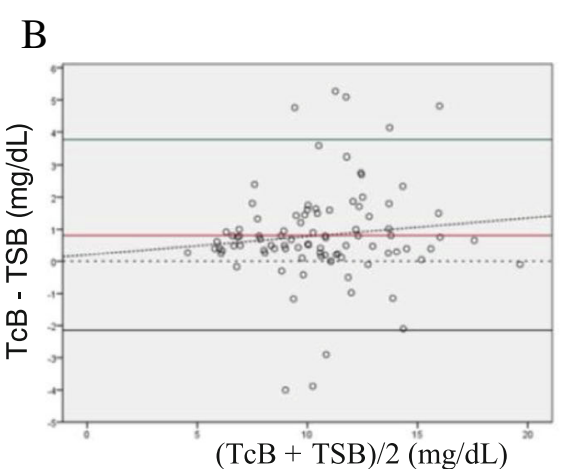

$\mathrm{D}$

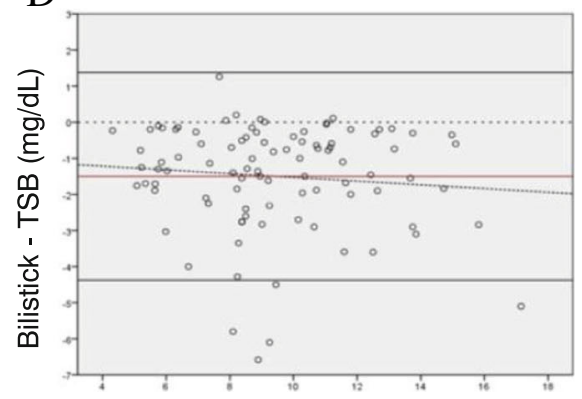

$($ Bilistick $+\mathrm{TSB}) / 2(\mathrm{mg} / \mathrm{dL})$

Fig. 1 Scatter and Bland Altman plot between TCB and TSB ( $\mathbf{a}$ and $\mathbf{b}$ ), Bilistick and TSB (c and $\mathbf{d}$ ) before phototherapy, $Y$ equation = linear equation obtained from linear regression analysis. $Y=$ estimated TSB, $X=$ Bilirubin level of the device being tested $(\longrightarrow$ ) = average difference $(\boldsymbol{C})$ agreement limit $\left(. \bullet^{\prime}\right)$ ) tendency of average difference $(\mathbf{m} \cdot \mathbf{m})=0$ point, standard to observe distance with red line 
A

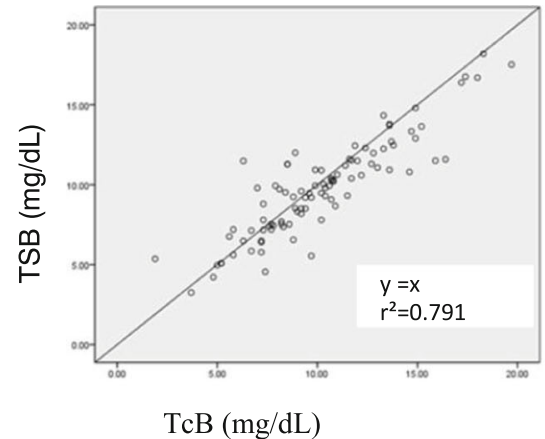

$\mathrm{C}$

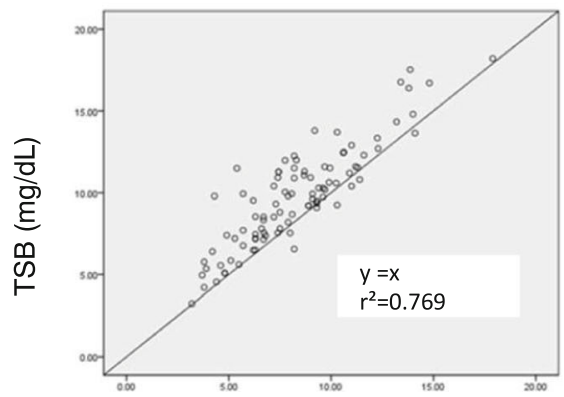

Bilistick (mg/dL)
B

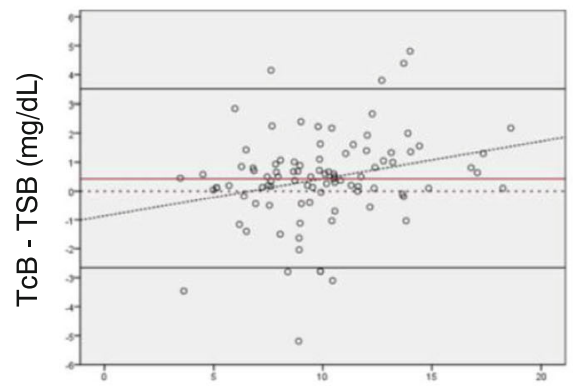

$(\mathrm{TcB}+\mathrm{TSB}) / 2(\mathrm{mg} / \mathrm{dL})$

$\mathrm{D}$

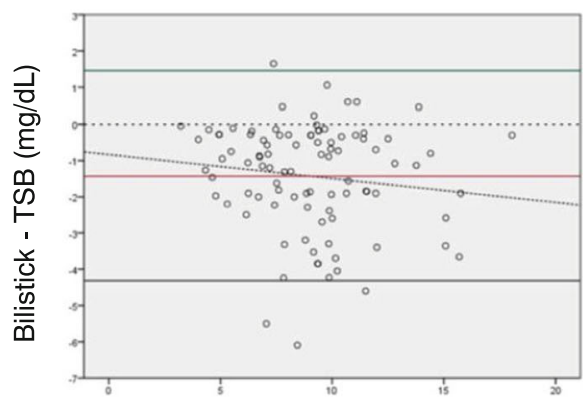

$($ Bilistick $+\mathrm{TSB}) / 2(\mathrm{mg} / \mathrm{dL})$

Fig. 2 Scatter and Bland Altman plots between TCB and TSB ( $\mathbf{a}$ and $\mathbf{b}$ ), Bilistick and TSB (c and $\mathbf{d}$ ) at $24 \mathrm{~h}$ of phototherapy. $Y$ equation $=$ linear equation obtained from linear regression analysis. $Y=$ estimated TSB, $X=$ Bilirubin level of the device being tested $(-$ ) $=$ average difference $(\boldsymbol{C})=$ agreement limit $\left(. \bullet^{\prime}\right)$ = tendency of average difference $(\mathbf{m} \cdot \mathbf{m})=0$ point, standard to observe distance with red line

Kolmogorov-Smirnov and Shapiro-Wilk test were used to test the normality of data, from which we obtained a normal distribution with $p>0.05$ for bilirubin measurement data before phototherapy and after $24 \mathrm{~h}$ of phototherapy. While for measurement of 48-h bilirubin phototherapy, we obtained an abnormal distribution with a value of $p<0.05$.

The Pearson correlation test of total serum bilirubin level and transcutaneous bilirubin before phototherapy showed a significant positive correlation between total serum bilirubin and transcutaneous bilirubin (Fig. 1a) $\left(r^{2}=0,764, p<0.0001\right)$.

Transcutaneous bilirubin levels tended to overestimate total serum bilirubin before phototherapy with a mean difference of $0.81 \mathrm{mg} / \mathrm{dL}$ (SD 1.51) with a $95 \%$ CI of 0.50 to 1.12 and the limits of agreement were -2.14 and $3.77 \mathrm{mg} / \mathrm{dL}$. The Bland-Altman plot shows that the higher the bilirubin level, the wider the difference between the 2 methods (Fig. 1b).

As shown in Fig. 1c there was a significant and positive correlation between total serum bilirubin and Bilistick bilirubin measurement before phototherapy $\left(r^{2}=0.753, p<0.0001\right)$.

Bilistick tended to underestimate total serum bilirubin before phototherapy measurement with a mean difference of $-1.50 \mathrm{mg} / \mathrm{dL}$ (SD 1.47) with a $95 \% \mathrm{CI}$ of -1.80 to 1.20 with the limits of agreement of -4.38 and $1.38 \mathrm{mg} /$ $\mathrm{dL}$. The Bland-Altman plot shows the higher the bilirubin level, the wider the difference between Bilistick and total serum bilirubin measurement (Fig. 1d).

After $24 \mathrm{~h}$ of phototherapy, we found a significant positive correlation between total serum bilirubin and transcutaneous bilirubin $\left(r^{2}=0.791, p<0.0001\right.$ (Fig. 2a). TcB overestimates total serum bilirubin with a mean difference of $0.43 \mathrm{mg} / \mathrm{dL}$ (SD 1.57) with $95 \%$ CI of 0.10 to 0.75 and limits of agreement of -2.66 and $3.51 \mathrm{mg} / \mathrm{dL}$ (Fig. 2b). There was a positive and significant correlation between total serum bilirubin and Bilistick bilirubin $\left(r^{2}=0.769, p<0.0001\right)$ (Fig. 2c). Bilistick underestimates total serum bilirubin with a mean difference $-1.43 \mathrm{mg} / \mathrm{dL}$ (SD 1.47) with $95 \% \mathrm{CI}-1.73$ to -1.13 and the limits of agreement were -4.32 and $1.46 \mathrm{mg} / \mathrm{dL}$. The Bland-Altman plot shows the higher the bilirubin level, the wider the difference between Bilistick and total serum bilirubin measurement (Fig. 2d).

The same pattern was observed after $48 \mathrm{~h}$ of phototherapy. A significant and positive correlation was present between total serum bilirubin and transcutaneous bilirubin $\left(r^{2}=0.771, p<0.0001\right)$ (Fig. 3a); TcB overestimates total serum bilirubin with a mean difference of $0.41 \mathrm{mg} / \mathrm{dL}$ (SD 1.58 ) with $95 \%$ CI 0.08 to 0.73 and the limits of agreement were -2.69 and $3.50 \mathrm{mg} / \mathrm{dL}$. The Bland-Altman plot shows that the higher the bilirubin level the wider the difference between transcutaneous bilirubin level and total 
A

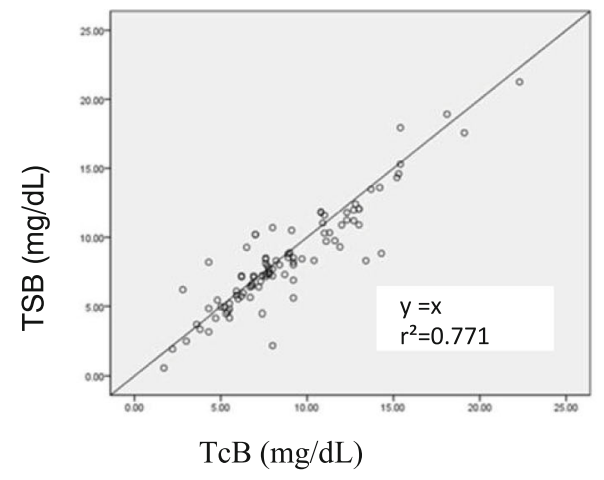

$\mathrm{C}$

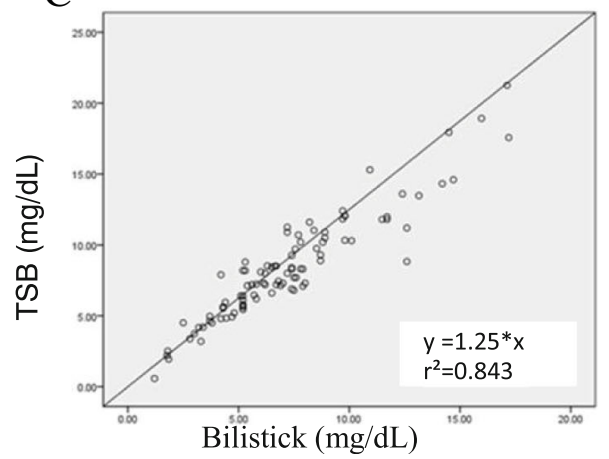

$\mathrm{B}$

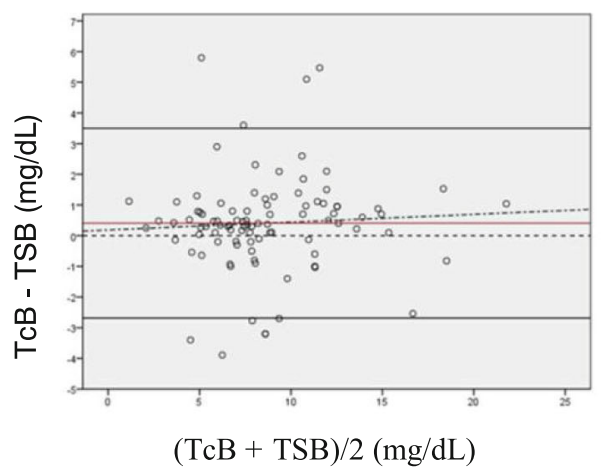

$\mathrm{D}$

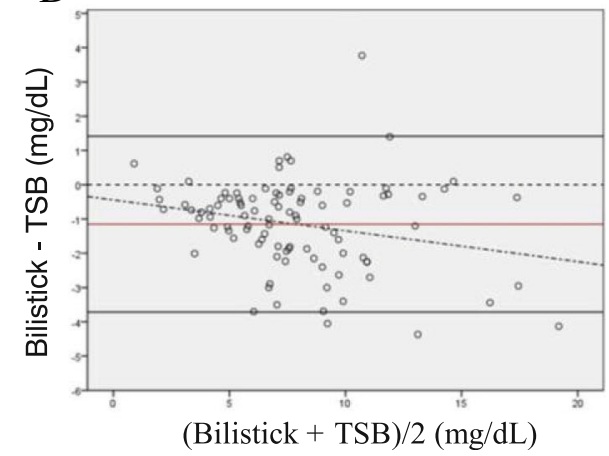

Fig. 3 Scatter and Bland Altman plot between TCB and TSB ( $\mathbf{a}$ and $\mathbf{b}$ ), Bilistick and TSB (c and $\mathbf{d}$ ) at $48 \mathrm{~h}$ of phototherapy. $Y$ equation $=$ linear equation obtained from linear regression analysis. $Y=$ estimated TSB, $X=$ Bilirubin level of the device being tested $(\longrightarrow)=$ average difference $(-)$ agreement limit $\left(. \bullet^{\prime}\right)=$ tendency of average difference $(\mathbf{m} \cdot \mathbf{m})=0$ point, standard to observe distance with red line

serum bilirubin (Fig. 3b). A significant and positive correlation was also found between total serum bilirubin and Bilistick $\left(r^{2}=0.843, p<0.0001\right)$ (Fig. 3c). Bilistick bilirubin tends to underestimate total serum bilirubin with a mean difference of $-1.15 \mathrm{mg} / \mathrm{dL}$ (SD 1.31) with $95 \% \mathrm{CI}-1.42$ to -0.88 and the limits of agreement were -3.72 and $1.42 \mathrm{mg} / \mathrm{dL}$. The Bland-Altman plot shows, the higher the bilirubin level, the wider the difference between Bilistick bilirubin level and total serum bilirubin (Fig. 3d).

\section{Discussion}

This study assessed the correlation and agreement of $\mathrm{TcB}$ and Bilistick bilirubin measurement with TSB before and during phototherapy in preterm infants of gestational age less than 35 weeks. There was a very strong and significant positive correlation between $\mathrm{TcB}$ and Bilistick bilirubin measurement with TSB before and after 24 or $48 \mathrm{~h}$ of phototherapy. The results we obtained were similar to the meta-analysis of TcB measurement in preterm infants [9]. Prior to phototherapy, JM 103 had a strong correlation of $r$ $=0.87$ (95\% CI of 0.82-0.91), and an even stronger correlation with preterm infants of less than 32 weeks $(r=0.89$ (95\% CI of 0.82-0.93)) [13]. Other studies obtained even stronger correlations in preterm infants with a gestational age of less than 28 weeks $(r=0.92$ and $r=0.94,[14,15])$. The result of correlation on 24-h phototherapy TcB measurement in our study was superior to previous studies in near term and term infants [9]. We assume this difference is due to our participants being premature infants with gestational ages of less than 35 weeks, as their thinner skin thickness may improve light absorption and reflection from the subcutaneous tissue to the appliance. The accuracy of Bilistick was also comparable with previous studies in term infants who did not receive phototherapy, suggesting that Bilistick may be reliably used in preterm infants before and after phototherapy $[10,11,13-16]$.

Measurement of TcB before phototherapy and after 24 and $48 \mathrm{~h}$ of phototherapy tended to overestimate by 0.81 , 0.43 , and $0.41 \mathrm{mg} / \mathrm{dL}$ compared with TSB. These results did not greatly differ from previous studies $[11,13,17,18]$. TcB measurement before phototherapy and after $24 \mathrm{~h}$ and $48 \mathrm{~h}$ of phototherapy overestimated bilirubin level with a mean difference of less than $1 \mathrm{mg} / \mathrm{dL}$ and showed very strong positive correlation. This led to the conclusion that TcB bilirubin measurement was reliable in preterm infants both before and during phototherapy. Why the TcB measurement tended to overestimate serum bilirubin is not clear, but we hypothesized that it is related to an increased 
blood flow in the skin, which is inversely proportional to weight gain and gestational age. This is revealed in our study of preterm infants with gestational ages of less than 35 weeks who have high blood flow and low skin thickness. Phototherapy increases blood flow in the skin by increasing the body temperature. An increase in body temperature of $0.5-1{ }^{\circ} \mathrm{C}$ leads to an increase of 3 times the blood flow in the skin [19]. In addition, some TcB devices while usable up to a bilirubin level of $20 \mathrm{mg} / \mathrm{dL}$, the reliability of the result is questionable at levels above $15 \mathrm{mg} / \mathrm{dL}$.

Bilistick measurement before phototherapy, and after $24 \mathrm{~h}$ and $48 \mathrm{~h}$ of phototherapy tended to underestimate by $1.5,1.43$, and $1.15 \mathrm{mg} / \mathrm{dL}$ compared with TSB. Bilistick measurement appears to be lower with a mean difference of less than $1.5 \mathrm{mg} / \mathrm{dL}$. This result is similar with what was reported in term infants who did not receive phototherapy [11]. Since this is the first study performed in preterms using the Bilistick system, additional data needs to be collected to verify that this small underestimation is correct.

Based on the tendency of both methods to overestimate or underestimate, the Indonesian guideline for phototherapy or exchange transfusion might require some changes in cases where doctors decide to use the Bilistick alone. This underestimation would have led to 11 neonates not receiving phototherapy when phototherapy would have been indicated by traditional serum bilirubin measurements in our population.

\section{Limitation}

We did not use the newest version of Bilistick because it was not available during our time of study [11]. The population of our study includes mostly patients of Sumatran and Javanese descent, in whom skin tones do not contrast greatly enough between light and dark skin tone for transcutaneous bilirubin results to show any of the discrepancies reported in Caucasian and African-American races [20-22]. We also did not have enough samples to statistically analyze the difference between extreme premature and premature babies.

\section{Conclusions}

Both $\mathrm{TcB}$ and Bilistick show equal reliability and can be used as an alternative measurement methods for monitoring bilirubin levels in term and preterm newborns, as well as before and after phototherapy. However, $\mathrm{TcB}$ tends to overestimate TSB while Bilistick underestimates TSB.

\section{Abbreviations}

Cl: Confidence Interval; RSCM: Cipto Mangunkusumo Hospital; SD: Standard deviation; SPSS: Statistical package for the social sciences;

TcB: Transcutaneous bilirubin; TSB: Total serum bilirubin

\section{Acknowledgements}

We would like to thank the nursing staff, physicians, and laboratory analysts at our neonatal ward and NICU for their helpful cooperation in this study, as well as Claudio Tiribelli for providing us the Bilistick system. We would also kindly thank Thomas Mayers for his valuable help in proofreading our manuscript.

\section{Availability of data and materials}

The datasets generated and/or analysed during the current study are not publicly available due to regulation by the hospital but are available from the corresponding author on reasonable request.

\section{Authors' contributions}

This work was carried out in collaboration between all authors. Authors IB, $\mathrm{EW}$, and RR designed the study and interpreted the data. Authors IB, $\mathrm{HO}$, and RA anchored the lab study, gathered the initial data, performed preliminary data analysis and managed the literature searches. Author IB and RDR produced the initial draft and IB, HAS, and RA wrote the manuscript. All authors read and approved the final manuscript.

\section{Ethics approval and consent to participate}

All authors hereby declare that all experiments have been examined and approved by the Ethics Committee of the Faculty of Medicine, Universitas Indonesia (No 783/UN2.F1/ETIK/2016) and have therefore been performed in accordance with the ethical standards laid down in the 1964 Declaration of Helsinki. A written informed consent was provided by the parents of the children involved in the study.

\section{Consent for publication}

Not applicable.

\section{Competing interests}

The authors declare that they have no competing interests.

\section{Publisher's Note}

Springer Nature remains neutral with regard to jurisdictional claims in published maps and institutional affiliations.

\section{Author details \\ 'Department of Child Health, Faculty of Medicine, Universitas Indonesia - Cipto Mangunkusumo Hospital, JI Pangeran Diponegoro No. 71, Salemba, Kenari, Senen, Jakarta Pusat, DKI Jakarta 10430, Indonesia. ${ }^{2}$ Neonatal Intensive Care Unit, Pondok Indah General Hospital, Jl Metro Duta Kav UE, Pondok Indah, Pondok Pinang, Kebayoran Lama, Jakarta Selatan, DKI Jakarta 12310, Indonesia.}

Received: 31 March 2018 Accepted: 24 September 2018

Published online: 29 September 2018

\section{References}

1. Kliegman RM, Behrman RE, Jenson HB, Stanton BM. Nelson textbook of pediatrics e-book: Elsevier. Health Sciences; 2007.

2. Martin RJ, Fanaroff AA, Walsh MC. Fanaroff and Martin's neonatal-perinatal medicine E-book: diseases of the fetus and infant. Elsevier Health Sciences; 2010.

3. Slim G, Naous A, Naja Z, Naja AS, Rajab M. Effect of Instituting a Hospital Pre-discharge Bilirubin Screening on Subsequent Significant Hyperbilirubinemia in Term and Near Term Newborn. 2015.

4. Arnolda G, Nwe H, Trevisanuto D, et al. Risk factors for acute bilirubin encephalopathy on admission to two Myanmar national paediatric hospitals. Matern Health Neonatol Perinatol. 2015;1(1):22.

5. Grabenhenrich J, Grabenhenrich L, Bührer C, Berns M. Transcutaneous bilirubin after phototherapy in term and preterm infants. Pediatrics. 2014; 134(5):e1324-9.

6. Szabo P, Wolf M, Bucher HU, Fauchere J-C, Haensse D, Arlettaz R. Detection of hyperbilirubinaemia in jaundiced full-term neonates by eye or by bilirubinometer? Eur J Pediatr. 2004;163(12):722-7.

7. Uwurukundo J, Baribwira C, Basinga P, Niyibizi P, Mutigima E. Assessing the accuracy of the jm-102 transcutaneous bilirubin measurement in dark skin jaundiced neonates: case of University Teaching Hospital, Rwanda. Rwanda Med J. 2013;69(2):39-44

8. Chang Y-H, Hsieh W-S, Chou H-C, Chen C-Y, Wu J-Y, Tsao P-N. The effectiveness of a noninvasive transcutaneous bilirubin meter in reducing the need for blood sampling in Taiwanese neonates. Clinical Neonatology. 2006;13(2):60-3.

9. Nagar G, Vandermeer B, Campbell S, Kumar M. Effect of phototherapy on the reliability of transcutaneous bilirubin devices in term and near-term infants: a systematic review and meta-analysis. Neonatology. 2016;109(3):203-12. 
10. Zabetta CC, Iskander I, Greco C, et al. Bilistick: a low-cost point-of-care system to measure total plasma bilirubin. Neonatology. 2013;103(3):177-81.

11. Greco C, Iskander I, Akmal D, et al. Comparison between Bilistick system and transcutaneous bilirubin in assessing total bilirubin serum concentration in jaundiced newborns. J Perinatol. 2017;37(9):1028.

12. Kosim MS, Yunanto A, Dewi R, Sarosa Gl, Usman A. Buku ajar neonatologi. Jakarta: IDI; 2008.

13. Nagar G, Vandermeer B, Campbell S, Kumar M. Reliability of transcutaneous bilirubin devices in preterm infants: a systematic review. Pediatrics. 2013;132(5):871-81.

14. Ahmed M, Mostafa S, Fisher G, Reynolds T. Comparison between transcutaneous bilirubinometry and total serum bilirubin measurements in preterm infants< 35 weeks gestation. Ann Clin Biochem. 2010;47(1):72-7.

15. Schmidt E, Wheeler C, Jackson G, Engle W. Evaluation of transcutaneous bilirubinometry in preterm neonates. J Perinatol. 2009:29(8):564.

16. Greco C, Arnolda G, Boo N-Y, et al. Neonatal jaundice in low-and middleincome countries: lessons and future directions from the 2015 don ostrow Trieste yellow retreat. Neonatology. 2016;110(3):172-80.

17. Campbell DM, Danayan KC, McGovern V, Cheema S, Stade B, Sgro M. Transcutaneous bilirubin measurement at the time of hospital discharge in a multiethnic newborn population. Paediatr Child Health. 2011;16(3):141-5.

18. Olusanya BO, Imosemi DO, Emokpae AA. Differences between transcutaneous and serum bilirubin measurements in black African neonates. Pediatrics. 2016;138:e20160907.

19. Wu PY, Wong W, Guerra G, et al. Peripheral blood flow in the neonate. 1. Changes in total, skin, and muscle blood flow with gestational and postnatal age. Pediatr Res. 1980;14(12):1374.

20. Taylor JA, Burgos AE, Flaherman V, et al. Discrepancies between transcutaneous and serum bilirubin measurements. Pediatrics. 2015;135(2):224-31.

21. Bhutta ZA, Yusuf K. Transcutaneous bilirubinometry in Pakistani newborns: a preliminary report. J Pakistan Med Assoc. 1991;41:155-6.

22. Wainer S, Rabi Y, Parmar SM, Allegro D, Lyon M. Impact of skin tone on the performance of a transcutaneous jaundice meter. Acta Paediatr. 2009;98(12):1909-15.

Ready to submit your research? Choose BMC and benefit from:

- fast, convenient online submission

- thorough peer review by experienced researchers in your field

- rapid publication on acceptance

- support for research data, including large and complex data types

- gold Open Access which fosters wider collaboration and increased citations

- maximum visibility for your research: over $100 \mathrm{M}$ website views per year

At $\mathrm{BMC}$, research is always in progress.

Learn more biomedcentral.com/submissions 